\title{
$\beta$-Amino functionalization of cinnamic Weinreb amides in ionic liquid
}

\author{
Yi-Ning Wang ${ }^{*}$, Guo-Xiang Sun and Gang Qi
}

\author{
Full Research Paper \\ Address: \\ School of Chemistry \& Chemical Engineering, Yancheng Institute of \\ Technology, Yancheng, Jiangsu 224051, China \\ Email: \\ Yi-Ning Wang ${ }^{*}$ - yining.wang@ycit.cn \\ ${ }^{*}$ Corresponding author \\ Keywords: \\ aminochlorination; $\beta$-amino functionalization; ionic liquid; Weinreb \\ amides
}

\author{
Beilstein J. Org. Chem. 2016, 12, 2372-2377. \\ doi:10.3762/bjoc. 12.231 \\ Received: 12 August 2016 \\ Accepted: 24 October 2016 \\ Published: 11 November 2016 \\ Associate Editor: R. Sarpong \\ (c) 2016 Wang et al.; licensee Beilstein-Institut. \\ License and terms: see end of document.
}

\begin{abstract}
2 -Ns-Protected $\beta$-amino Weinreb amides were synthesized by aminochlorination of $\alpha, \beta$-unsaturated Weinreb amides in an ionic liquid, 1- $n$-butyl-3-methylimidazolium bis(trifluoromethanesulfonyl)imide ([BMIM] $\left.\mathrm{NTf}_{2}\right]$ ). Processed without the use of metal catalysts or the need of an inert gas atmosphere, the presented process can be readily performed as a one-pot synthesis at room temperature. Moreover, the preparation has the distinct advantages of the use of $2-\mathrm{NsNCl}_{2}$ as an inexpensive and stable nitrogen/ halogen source and the ionic liquid as a recyclable reaction media. Nine examples were examined, and modest to good isolated chemical yields (40-83\%) were obtained.
\end{abstract}

\section{Introduction}

Unlike $N$-protected $\alpha$-amino carbonyl compounds, their analogues, the $\beta$-amino carbonyl compounds, have drawn relatively little attention. However, the $\beta$-amino carbonyl moieties are not only found in natural products [1-3], e.g., in the side chain of Taxol, but also in important building blocks widely used in the organic syntheses. They are especially used in the synthesis of $\beta$-amino acids $[4,5]$, which are precursors for many biological and pharmacological active compounds, such as $\beta$-lactams [6] and $\beta$-peptides [7]. The most straightforward approach towards the preparation of $\beta$-amino carbonyl compounds is the Mannich reaction $[8,9]$. However, there are few reported methods specifically focused on this target, which include oxidation of $\gamma$-amino alcohols [10], hydrolysis of 1,3-oxazines [11], rearrangement of 2,3-aziridinio alcohols [12], etc.

$N$-Methoxy- $N$-methylamides, known as Weinreb amides, were first reported by Nahm and Weinreb in 1981 [13]. Since then, the Weinreb amides were found to be useful precursors for the synthesis of their carbonyl equivalents in organic chemistry [14]. By treating with various nucleophiles, such as hydrides, Grignard and organolithium reagents or ester enolates, the Weinreb amides can be easily converted into aldehydes, ke- 
tones, and $\beta$-keto esters, respectively [13-20]. Therefore, the transformation of $\beta$-amino Weinreb amides can provide a promising pathway towards the achievement of $\beta$-amino carbonyl derivatives. Surprisingly, there have been only a few successful preparations for $\beta$-amino Weinreb amides to date. One of which is the addition of the enolate of commercially available $\mathrm{N}$-methoxy- $N$-methylacetamide to sulfinimines to generate the corresponding $N$-sulfinyl $\beta$-amino Weinreb amides [21-26]. Another approach was the direct amination of $\alpha, \beta$-unsaturated Weinreb amides by using lithium $(S)$ - $N$-benzyl- $N$ - $\alpha$-methylbenzylamide as the nitrogen source [27-29]. Recently, a new chiral $N$-phosphonylimine chemistry was developed by the Li group. By reacting $N$-phosphonylimines 1 with Weinreb amides, $N$-phosphonyl- $\beta$-amino Weinreb amides 2 can be obtained (Scheme 1) [30]. Although great progress has already been achieved, there were still some limitations in the existing syntheses of $\beta$-amino Weinreb amides, such as the difficult syntheses of starting materials or the harsh reaction conditions required for the removal of the $N$-protecting groups.

With the aminochlorination developed in the past few years [31], we found that when the aminochlorination reactions of $\alpha, \beta$-unsaturated ketones 3 were carried out in ionic liquid, [BMIM] $\left[\mathrm{NTf}_{2}\right]$ (1- $n$-butyl-3-methylimidazolium bis(trifluoromethanesulfonyl)imide, $\mathrm{Tf}=\mathrm{SO}_{2} \mathrm{CF}_{3}$ ), a series of $\alpha$-chloro- $\beta$ amino ketone derivatives 4 could be obtained with excellent regioselectivities (Scheme 2) [32]. Encouraged by these promising results, we thought that the $\alpha, \beta$-unsaturated Weinreb amides could be potential substrates for the preparation of $\beta$-amino Weinreb amides. Compared with the reported methods, there are several advantages for the proposed aminochlorination reactions: 1) it is much easier to achieve the starting materials, in- cluding the $\alpha, \beta$-unsaturated Weinreb amides and the nitrogen sources, such as $4-\mathrm{TsNCl}_{2}$ and $2-\mathrm{NsNCl}_{2} ; 2$ ) the removal of the $\mathrm{N}$-protecting groups is relatively easier than those shown above; and 3 ) the ionic liquids are environmentally friendly and can be readily recycled.

\section{Results and Discussion}

The first attempt was to conduct the aminochlorination reaction of $N$-methoxy- $N$-methylcinnamoylamide (5a) in acetonitrile by using $2-\mathrm{NsNCl}_{2}$ as the nitrogen source and $\mathrm{Cu}(\mathrm{I}) \mathrm{OTf}$ as the metal catalyst $[33,34]$. However, there no aminochlorination products were observed. Next, we turned our attention to the use of ionic liquids, which have shown many significant advantages in the reported aminochlorination reactions [35-37]. However, when the ionic liquid $[\mathrm{BMIM}]\left[\mathrm{BF}_{4}\right]$ was utilized as the reaction media, no anticipated haloamine products were detected, which was similar to the aminochlorination of $\alpha, \beta$ unsaturated ketones [32]. Fortunately, when we switched the ionic liquid to [BMIM] $\left[\mathrm{NTf}_{2}\right]$, it was found that the starting material, $N$-methoxy- $N$-methylcinnamoylamide (5a), was consumed completely after $24 \mathrm{~h}$ without utilizing any metal catalysts. Furthermore, under the optimized reaction conditions, the isolated chemical yield of the $\beta$-amino product could be increased up to $81 \%$ (Table 1 ). A series of common $\alpha, \beta$-unsaturated Weinreb amides were systematically investigated as well. Similarly, the aminochlorination reactions proceeded smoothly, and the anticipated $\alpha$-chloro- $\beta$-amino products were obtained in modest to good yields and excellent regioselectivities (Table 2).

Different from the similar aminochlorination reactions of $\alpha, \beta$ unsaturated ketones mediated in the same ionic liquid, two different isomers were formed nearly equally. However, these dia-
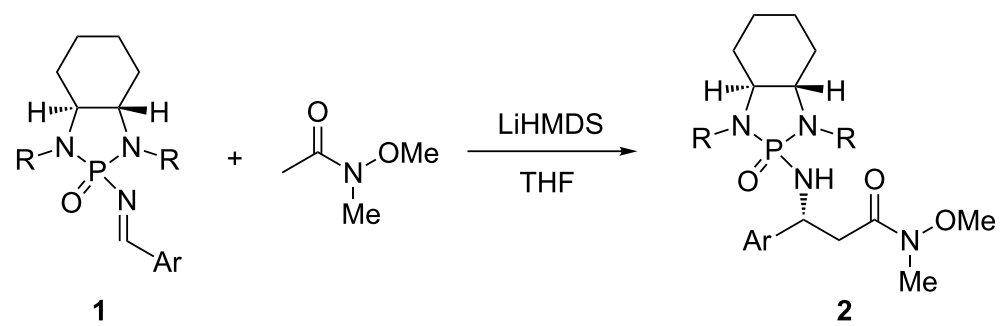

Scheme 1: Synthesis of $N$-phosphonyl- $\beta$-amino Weinreb amides.

$$
\mathrm{R}_{\mathrm{R}^{2}} \overbrace{\text { 2) } \mathrm{Na}_{2} \mathrm{SO}_{3}(\mathrm{aq})}^{\mathrm{O}}+\mathrm{NsNCl}_{2} \frac{\text { 1) } 4 \AA \mathrm{MS},[\mathrm{BMIM}]\left[\mathrm{NTf}_{2}\right]}{\longrightarrow}
$$

3

$( \pm)-4$ 
Table 1: Optimization of aminochlorination of $N$-methoxy- $N$-methylcinnamoylamide (5a).

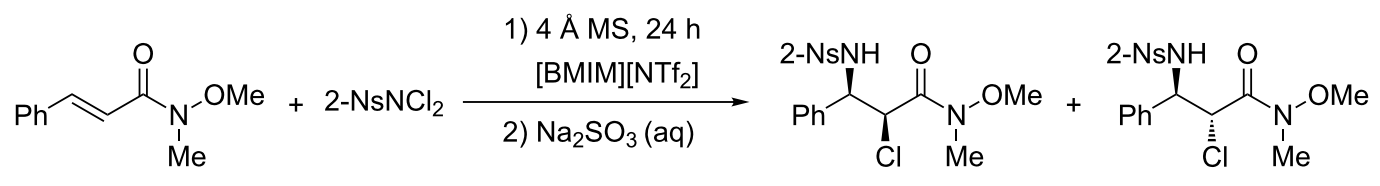

$5 \mathbf{a}$

$( \pm)-6 a-A$

( \pm )-6a-B

\begin{tabular}{llll}
\hline Entry & Temp $\left({ }^{\circ} \mathrm{C}\right)$ & Cu(I)OTf & ${\text { Yield }(\%)^{\mathrm{a}}}^{\mathrm{a}}$ \\
\hline 1 & 25 & - & 81 \\
2 & 25 & $10 \mathrm{~mol} \%$ & 71 \\
3 & 80 & - & 60 \\
4 & 80 & $10 \mathrm{~mol} \%$ & 61 \\
\hline
\end{tabular}

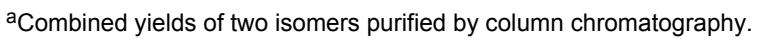

Table 2: Results of aminochlorination of $\alpha, \beta$-unsaturated Weinreb amides.

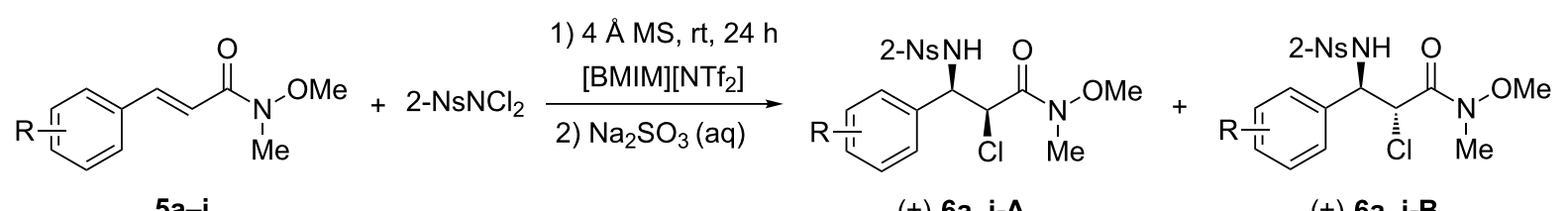

5a-i

$( \pm)-6 a-i-A$

(士)-6a-i-B

\begin{tabular}{llllll}
\hline Entry & Substrate & R & Product & Yield $^{\text {a }}$ \%) & Stereoselectivity $^{\mathrm{b}}(\mathbf{A}: \mathbf{B})$ \\
\hline 1 & $\mathbf{5 a}$ & $\mathbf{H}$ & $\mathbf{6 a}$ & 81 & $1.0: 1.3$ \\
2 & $\mathbf{5 b}$ & 2-fluoro & $\mathbf{6 b}$ & 83 & $1.0: 1.5$ \\
3 & $\mathbf{5 c}$ & 4-chloro & $\mathbf{6 c}$ & 70 & $1.0: 1.4$ \\
4 & $\mathbf{5 d}$ & 2,4-dichloro & $\mathbf{6 d}$ & 79 & $1.0: 1.8$ \\
5 & $\mathbf{5 e}$ & 4-bromo & $\mathbf{6 e}$ & 79 & $1.0: 1.3$ \\
6 & $\mathbf{5 f}$ & 4-methyl & $\mathbf{6 f}$ & 78 & $1.0: 1.2$ \\
7 & $\mathbf{5 g}$ & 4-methoxy & $\mathbf{6 g}$ & 63 & $1.0: 1.2$ \\
8 & $\mathbf{5 h}$ & 4-phenyl & $\mathbf{6 h}$ & 69 & $1.0: 0.7$ \\
9 & $\mathbf{5 i}$ & 4-naphthyl & $\mathbf{6 i}$ & 40 & $1.0: 0.7$ \\
\hline
\end{tabular}

${ }^{\mathrm{a} C}$ Combined yields of two isomers separated by column chromatography. ${ }^{\mathrm{b}}$ Determined after column chromatography.

stereomers can be easily separated by flash column chromatography. The regioselectivities of the isomers were determined by mass spectrometric analyses, both of which prominent peaks corresponding to $[\mathrm{PhCHNHNs}]^{+}(m / z=291)$ could be clearly observed. The results indicated that the isolated products were both $\alpha$-chloro- $\beta$-amino Weinreb amide derivatives. The assignments for the stereoselectivities were determined by the conversions of the diastereomers to their corresponding aziridines (Scheme 3), and diastereomers 6a-A and 6a-B were chosen as representative substrates. Based on the vicinal Karplus correlation diagram, the vicinal proton coupling constants in the ${ }^{1} \mathrm{H}$ NMR spectra of cis-aziridines are larger than those of transazridines $[38,39]$. In the ${ }^{1} \mathrm{H}$ NMR spectra of the resulting aziridines derived from compounds $\mathbf{6 a - A}$ and $\mathbf{6 a - B}$, the vicinal proton coupling constants were $7.5 \mathrm{~Hz}$ and $4.5 \mathrm{~Hz}$, respectively. Therefore, compound 6a-A was assigned as $s y n$-stereoisomer, and compound 6a-B was assigned as anti-stereoisomer.

In the ${ }^{1} \mathrm{H}$ NMR spectra of the isolated diastereomers, an obvious and interesting phenomenon can be seen; namely, the difference of the proton chemical shifts of the hydrogen atoms of the nitrobenzenesulfonylamines. Compared with the chemical shifts of these protons belonging to the syn-stereoisomers, the signals of the same kind of protons of the anti-stereoisomers move to much lower fields (e.g., $8.25 \mathrm{ppm}$ vs $6.33 \mathrm{ppm}$ for compounds $\mathbf{6 a - B}$ vs $\mathbf{6 a - A}$ ). The reason for this phenomenon 


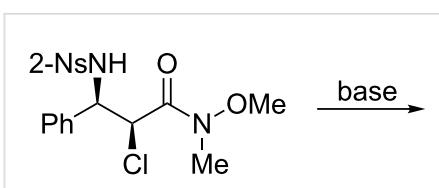

$( \pm)-6 a-A$<smiles>CON(C)C(=O)[C@H](Cl)[C@H](NS(=O)(=O)[O-])c1ccccc1</smiles>

$( \pm)-6 \mathbf{a}-\mathbf{B}$

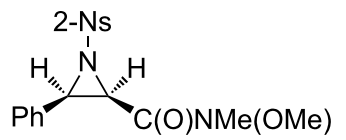

$( \pm)-7-A$

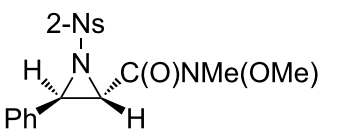

(士)-7-B
Scheme 3: Conversion of $\beta$-amino Weinreb amides to aziridines.

is probably due to hydrogen bonding between the protons of the nitrobenzenesulfonyl amines and the neighboring carbonyl groups, which form stable six-membered rings as shown in Figure 1. In addition, because of the resonance structures (Scheme 4), the hydrogen bonding can be further strengthened by the oxygen which is more electronegative. As a result, the chemical shifts of these protons belonging to the anti-stereoisomers can move to much lower fields than those of the similar hydrogen atoms of not only the syn-stereoisomers but also the $\beta$-amino compounds derived from $\alpha, \beta$-unsaturated ketones. This hypothesis can be supported by an unexpected transformation. When aziridine 7-B was purified by flash column chromatography, part of the aziridine ring was opened by a chlorine anion to form the $\alpha$-amino- $\beta$-chloro Weinreb amide derivative 8 (Scheme 5). This could be confirmed by mass spectroscopic analysis as well. In its mass spectrum, a prominent peak denoting $[\mathrm{NsNHCHC}(\mathrm{O}) \mathrm{NMe}(\mathrm{OMe})]^{+}(\mathrm{m} / z=302)$ was exclusively observed. Because compound $\mathbf{8}$ was derived from transaziridine, it should be the trans-regioisomer of compound 6a-B. As expected, its proton chemical shift of nitrobenzenesulfonylamine was only $6.20 \mathrm{ppm}$.

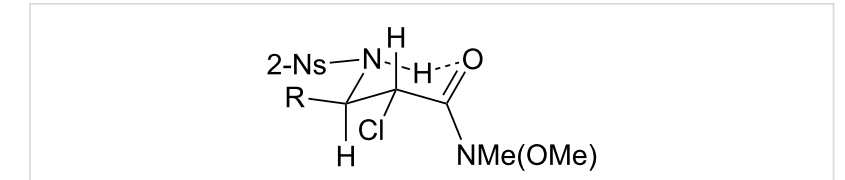

Figure 1: Possible hydrogen bonding conformation.

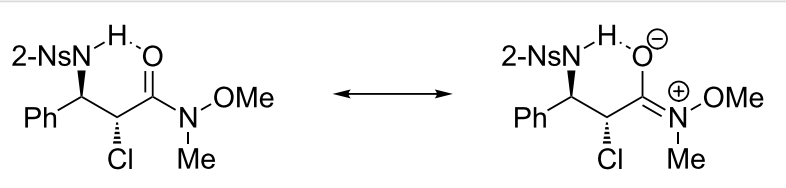

Scheme 4: Resonance structures of Weinreb amides.

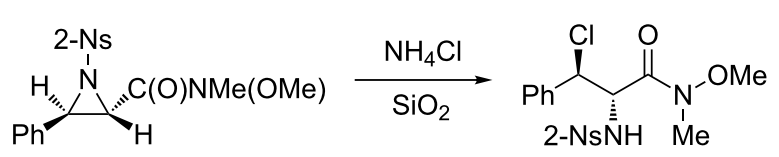

$( \pm)-7-B$

$( \pm)-8$
Scheme 5: Transformation of trans-aziridine.

As shown in Table 2, nearly 1:1 stereoselectivities were observed in all cases. This indicated that instead of a chlorinium or aziridinium ion intermediate, as hypothesized in the previous analogous reactions, a relatively stable carbocation intermediate was more likely to have formed in this aminochlorination reaction (Scheme 6). Moreover, when the carbocation intermediate was formed, strong electron-withdrawing groups at the phenyl ring in the 3-position of the carbocation are highly disfavored for the aminochlorination reaction. For example, when the nitro group was attached to the phenyl ring, no aminochlorination reaction took place, and only starting material remained even after stirring for a long time.<smiles></smiles> 


\section{Conclusion}

A new approach to afford $\beta$-amino Weinreb amides was achieved by the aminochlorination of $\alpha, \beta$-unsaturated Weinreb amides. The new process has the advantages that the starting materials can be easily achieved and the $N$-protecting groups simply removed. Additionally, the reactions can be readily performed in the ionic liquid [BMIM] $\left[\mathrm{NTf}_{2}\right]$ at room temperature without the use of metal catalysts or the need for inert gases protection, and the final products can be easily isolated by flash column chromatography. Compared with the existing methods, the aminochlorination reactions of $\alpha, \beta$-unsaturated Weinreb amides provided a promising direction towards the preparation of $\beta$-amino Weinreb amides, which have shown great importance in not only organic synthesis, but also in medicinal and pharmaceutical chemistry.

\section{Experimental}

General procedure: $\alpha, \beta$-Unsaturated Weinreb amides were prepared following literature methods [40]. The ionic liquid $[\mathrm{BMIM}]\left[\mathrm{NTf}_{2}\right]$ was readily prepared by reacting 1-methylimidazole with $n$-butyl bromide [41-43], followed by anion metathesis using $N$-lithiotrifluoromethanesulfonimide in acetone solution. The resulting ionic liquid, [BMIM] $\left[\mathrm{NTf}_{2}\right]$, was carefully dried by heating at $60{ }^{\circ} \mathrm{C}$ in vacuum, then confirmed by ${ }^{1} \mathrm{H}$ NMR analysis [44]. All aminochlorination reactions were performed in oven-dried vials. Flash column chromatography was performed using silica gel (Merck 60, 230-400 mesh). ${ }^{1} \mathrm{H}$ and ${ }^{13} \mathrm{C}$ NMR spectra were obtained with Varian Inova $500 \mathrm{MHz}$ and Varian Mercury Plus $300 \mathrm{MHz}$ spectrometers using deuterated chloroform as a solvent. Internal TMS $(\delta=0.0 \mathrm{ppm})$ was used as the reference for ${ }^{1} \mathrm{H} \mathrm{NMR}$, while the deuterated chloroform peak $(\delta=77.0 \mathrm{ppm})$ was used as the reference for ${ }^{13} \mathrm{C} \mathrm{NMR}$.

Typical procedure for the aminochlorination of $\boldsymbol{\alpha}, \boldsymbol{\beta}$-unsaturated Weinreb amides 5a-i: Analogous to the procedure described in [32], $N$-methoxy- $N$-methylcinnamoylamide (5a, $96 \mathrm{mg}, 0.5 \mathrm{mmol}, 1.0$ equiv), $4 \AA$ molecular sieves (100 mg), $2-\mathrm{NsNCl}_{2}$ (163 mg, $0.6 \mathrm{mmol}, 1.2$ equiv) and [BMIM][ $\left.\mathrm{NTf}_{2}\right]$ $(500 \mathrm{mg})$ were loaded into an oven-dried vial. The resulting mixture was stirred at room temperature for $24 \mathrm{~h}$. The reaction was finally quenched with saturated aqueous $\mathrm{Na}_{2} \mathrm{SO}_{3}$ solution. The product was extracted with ethyl acetate $(5 \mathrm{~mL} \times 3)$ and the combined organic phases were washed with brine and dried over anhydrous $\mathrm{Na}_{2} \mathrm{SO}_{4}$. The crude product was subjected to flash column chromatography (EtOAc/dichloromethane/hexane, $\mathrm{v} / \mathrm{v} / \mathrm{v}=1: 3: 2)$ to yield $174 \mathrm{mg}$ of product as a white solid $(81 \%)$.

Typical procedure for the preparation of aziridines 7A and 7B: The $\beta$-amino Weinreb amide $(\mathbf{6 a - A}$ or $\mathbf{6 a - B}, 70 \mathrm{mg}$,
$0.16 \mathrm{mmol}, 1.0$ equiv), dichloromethane $(5 \mathrm{~mL})$ and triethylamine $(0.1 \mathrm{~mL})$ were loaded into an oven-dried vial. After stirring at room temperature for $24 \mathrm{~h}$, the reaction mixture was concentrated to dryness and purified by flash column chromatography $(E t O A c / h e x a n e, v / v=1: 3)$ to yield the product as a white solid.

\section{Supporting Information}

\section{Supporting Information File 1}

Full compound characterization data for products $6 \mathbf{a}-\mathbf{i}, \mathbf{7 A}$, 7B and 8.

[http://www.beilstein-journals.org/bjoc/content/ supplementary/1860-5397-12-231-S1.pdf]

\section{Acknowledgements}

We gratefully acknowledge the Talent Introduction Funding of Yancheng Institute of Technology for its generous support of this work.

\section{References}

1. Davis, F. A.; Szewczyk, J. M. Tetrahedron Lett. 1998, 39, 5951-5954. doi:10.1016/S0040-4039(98)01223-4

2. Bates, R. W.; Sa-Ei, K. Tetrahedron 2002, 58, 5957-5958. doi:10.1016/S0040-4020(02)00584-7

3. Seebach, D.; Kimmerlin, T.; Šebesta, R.; Campo, M. A.; Beck, A. K. Tetrahedron 2004, 60, 7455-7506. doi:10.1016/j.tet.2004.06.043

4. Liu, M.; Sibi, M. P. Tetrahedron 2002, 58, 7991-8035. doi:10.1016/S0040-4020(02)00991-2

5. Weiner, B.; Szymański, W.; Janssen, D. B.; Minnaard, A. J.; Feringa, B. L. Chem. Soc. Rev. 2010, 39, 1656-1691. doi:10.1039/b919599h

6. Alcaide, B.; Almendros, P.; Aragoncillo, C. Chem. Rev. 2007, 107, 4437-4492. doi:10.1021/cr0307300

7. Cheng, R. P.; Gellman, S. H.; DeGrado, W. F. Chem. Rev. 2001, 101, 3219-3232. doi:10.1021/cr000045i

8. Ting, A.; Schaus, S. E. Eur. J. Org. Chem. 2007, 5797-5815. doi:10.1002/ejoc.200700409

9. Verkade, J. M. M.; van Hemert, L. J. C.; Quaedflieg, P. J. L. M.; Rutjes, F. P. J. T. Chem. Soc. Rev. 2008, 37, 29-41. doi:10.1039/b713885g

10. Davies, S. B.; McKervey, M. A. Tetrahedron Lett. 1999, 40, 1229-1232. doi:10.1016/S0040-4039(98)02573-8

11. Gizecki, P.; Dhal, R.; Toupet, L.; Dujardin, G. Org. Lett. 2000, 2, 585-588. doi:10.1021/ol991326j

12. Wang, B. M.; Song, Z. L.; Fan, C. A.; Tu, Y. Q.; Shi, Y. Org. Lett. 2002, 4, 363-366. doi:10.1021/ol0170410

13. Nahm, S.; Weinreb, S. M. Tetrahedron Lett. 1981, 22, 3815-3818. doi:10.1016/S0040-4039(01)91316-4

14. Sibi, M. P. Org. Prep. Proced. Int. 1993, 25, 15-40. doi:10.1080/00304949309457931

15. Turner, J. A.; Jacks, W. S. J. Org. Chem. 1989, 54, 4229-4231. doi:10.1021/jo00278a047 
16. Murphy, J. A.; Commeureuc, A. G. J.; Snaddon, T. N.; McGuire, T. M.; Khan, T. A.; Hisler, K.; Dewis, M. L.; Carling, R. Org. Lett. 2005, 7, 1427-1429. doi:10.1021/ol050337b

17. Kojima, S.; Hidaka, T.; Yamakawa, A. Chem. Lett. 2005, 34, 470-471. doi:10.1246/cl.2005.470

18. Qu, B.; Collum, D. B. J. Org. Chem. 2006, 71, 7117-7119. doi:10.1021/jo061223w

19. Persson, T.; Nielsen, J. Org. Lett. 2006, 8, 3219-3222. doi:10.1021/ol0611088

20. Rudzinski, D. M.; Kelly, C. B.; Leadbeater, N. E. Chem. Commun. 2012, 48, 9610-9612. doi:10.1039/C2CC35037H

21. Davis, F. A.; Prasad, K. R.; Brad Nolt, M.; Wu, Y. Org. Lett. 2003, 5, 925-927. doi:10.1021/ol034119z

22. Davis, F. A.; Yang, B. Org. Lett. 2003, 5, 5011-5014. doi:10.1021/ol035981+

23. Davis, F. A.; Brad Nolt, M.; Wu, Y.; Prasad, K. R.; Li, D.; Yang, B.; Bowen, K.; Lee, S. H.; Eardley, J. H. J. Org. Chem. 2005, 70, 2184-2190. doi:10.1021/jo0402780

24. Davis, F. A.; Song, M. Org. Lett. 2007, 9, 2413-2416. doi:10.1021/ol0708166

25. Davis, F. A.; Theddu, N. J. Org. Chem. 2010, 75, 3814-3820. doi:10.1021/jo100680b

26. Davis, F. A.; Xu, P. J. Org. Chem. 2011, 76, 3329-3337. doi:10.1021/jo2002352

27. Davies, S. G.; McCarthy, T. D. Synlett 1995, 700-702. doi:10.1055/s-1995-5059

28. Davies, S. G.; Iwamoto, K.; Smethurst, C. A. P.; Smith, A. D.; Rodriguez-Solla, H. Synlett 2002, 1146-1148. doi:10.1055/s-2002-32580

29. Burke, A. J.; Davies, S. G.; Garner, A. C.; McCarthy, T. D.; Roberts, P. M.; Smith, A. D.; Rodriguez-Solla, H.; Vickers, R. J. Org. Biomol. Chem. 2004, 2, 1387-1394. doi:10.1039/B402531H

30. Kaur, P.; Nguyen, T.; Li, G. Eur. J. Org. Chem. 2009, 912-916. doi:10.1002/ejoc.200801061

31. Chemler, S. R.; Bovino, M. T. ACS Catal. 2013, 3, 1076-1091. doi:10.1021/cs400138b

32. Wang, Y.-N.; Ni, B.; Headley, A. D.; Li, G. Adv. Synth. Catal. 2007, 349, 319-322. doi:10.1002/adsc.200600277

33. Li, G.; Wei, H.-X.; Kim, S. H.; Neighbors, M. Org. Lett. 1999, 1, 395-398. doi:10.1021/ol990059e

34. Li, G.; Wei, H.-X.; Kim, S. H. Org. Lett. 2000, 2, 2249-2252. doi:10.1021/ol000120b

35. Kotti, S. R. S. S.; Xu, X.; Wang, Y.; Headley, A. D.; Li, G. Tetrahedron Lett. 2004, 45, 7209-7212. doi:10.1016/j.tetlet.2004.08.040

36. Xu, X.; Kotti, S. R. S. S.; Liu, J.; Cannon, J. F.; Headley, A. D.; Li, G. Org. Lett. 2004, 6, 4881-4884. doi:10.1021/ol048045i

37. Wang, Y.-N.; Kattuboina, A.; Ai, T.; Banerjee, D.; Li, G. Tetrahedron Lett. 2007, 48, 7894-7898. doi:10.1016/j.tetlet.2007.08.099

38. Ploux, O.; Caruso, M.; Chassaing, G.; Marquet, A. J. Org. Chem. 1988, 53, 3154-3158. doi:10.1021/jo00249a006

39. Davis, F. A.; Zhou, P.; Reddy, G. V. J. Org. Chem. 1994, 59 , 3243-3245. doi:10.1021/jo00091a001

40. De Luca, L.; Giacomelli, G.; Taddei, M. J. Org. Chem. 2001, 66, 2534-2537. doi:10.1021/jo015524b

41. Earle, M. J.; McCormac, P. B.; Seddon, K. R. Green Chem. 1999, 23-25. doi:10.1039/A808052F

42. Sheldon, R. Chem. Commun. 2001, 2399-2407. doi:10.1039/B107270F
43. Wu, J. X.; Beck, B.; Ren, R. X. Tetrahedron Lett. 2002, 43, 387-389. doi:10.1016/S0040-4039(01)02168-2

44. Lucas, P.; El Mehdi, N.; Anh Ho, H.; Bélanger, D.; Breau, L. Synthesis 2000, 1253-1258. doi:10.1055/s-2000-6416

\section{License and Terms}

This is an Open Access article under the terms of the Creative Commons Attribution License

(http://creativecommons.org/licenses/by/4.0), which permits unrestricted use, distribution, and reproduction in any medium, provided the original work is properly cited.

The license is subject to the Beilstein Journal of Organic Chemistry terms and conditions:

(http://www.beilstein-journals.org/bjoc)

The definitive version of this article is the electronic one which can be found at: doi:10.3762/bjoc. 12.231 